\title{
1. SHATSKY RISE: SEISMIC STRATIGRAPHY AND SEDIMENTARY RECORD OF PACIFIC PALEOCEANOGRAPHY SINCE THE EARLY CRETACEOUS ${ }^{1}$
}

\author{
William V. Sliter ${ }^{2}$ and Glenn R. Brown ${ }^{3}$
}

\begin{abstract}
Shatsky Rise consists of three highs arranged in a linear trend more than $1300 \mathrm{~km}$ long. Shatsky Plateau, the southernmost and largest of three highs is represented by an exposed basement high of presumed Late Jurassic age flanked by a sedimentary sequence of at least Cretaceous and Cenozoic age that reaches a maximum thickness of more than $1100 \mathrm{~m}$. Drilling on Shatsky Rise is restricted to eight DSDP and ODP sites on the southern plateau that partially penetrated the sedimentary sequence. Leg 132 seismic profiles and previous seismic records from Shatsky Plateau reveal a five-part seismic section that is correlated with the drilling record and used to interpret the sedimentary history of the rise. The seismic sequence documents the transit of Shatsky Plateau beneath the equatorial divergence in the Late Cretaceous by horizontal plate motion from an original location in the Southern Hemisphere. Unconformities and lithologic changes bounding several of the seismic units are correlated with paleoceanographic changes that resulted in erosional events near the Barremian/Aptian, Cenomanian/Turonian, and Paleogene/Neogene boundaries.
\end{abstract}

\section{INTRODUCTION}

Shatsky Rise, the second largest oceanic plateau in the Pacific Ocean, was one of three drilling targets on Ocean Drilling Program (ODP) Leg 132. The primary goals of Leg 132 were to test the new version of the ODP developmental diamond-coring system (DCS) in various problem lithologies where previous rotary coring had proved inadequate. One of these problem lithologies, namely the drilling and recovery of alternating hard and soft chert-chalk sequences, was particularly well known from Shatsky Rise. Previous drilling on Deep Sea Drilling Project (DSDP) Legs 6, 32, and 86 (Fischer, Heezen, et al., 1971; Larson, Moberly, et al., 1975; Heath, Burkle, et al., 1985), respectively, found chert in sediment of Mesozoic age that severely effected recovery in and below the Santonian section.

Scientifically, we had hoped that by targeting the chert-chalk sequence of Aptian-Albian age for the DCS test we would recover organic carbon-rich intervals known to occur in the sedimentary sequence of this age and thus to better understand black shale deposition in the Pacific basin. Unfortunately, a combination of operational and meteorological problems prevented employment of the DCS and coring on Shatsky Rise was limited to a section of Cretaceous (Maastrichtian) to Cenozoic nannofossil ooze recovered with the advanced piston corer (see Premoli Silva et al., this volume). As a result, the pelagic cap of Shatsky Rise that attains a thickness of more than $1000 \mathrm{~m}$ remains only partially cored and volcanic basement has not been reached.

Here we present seismic reflection data from Leg 132 for Shatsky Rise and synthesize these with previous geophysical and drilling results to interpret the sedimentologic history of the Rise in anticipation of future exploration.

\section{Shatsky Rise}

Shatsky Rise is a broad elevation in the west-central Pacific (Fig. 1) with an area of about $7.5 \times 10^{5} \mathrm{~km}$, or roughly comparable in size to the state of California. The Rise consists of three prominent highs arranged in a northeasterly trend. The southern high, Shatsky

${ }^{1}$ Natland, J.H., Storms, M.A., et al., 1993. Proc. ODP, Sci. Results, 132: College Station, TX (Ocean Drilling Program),

${ }^{2}$ U.S. Geological Survey, 345 Middlefield Road, MS 915, Menlo Park, CA 94025, U.S.A.

${ }^{3}$ Department of Geology, University of Toronto, Toronto, Ontario M55 3B1, Canada.
Plateau, is the largest with a length of about $700 \mathrm{~km}$ and a width of about $300 \mathrm{~km}$. All previous DSDP and ODP drill sites are located on the southern plateau (Fig. 2). The regional magnetic anomalies of the abyssal Pacific seafloor surrounding Shatsky Rise exhibit a nearly orthogonal pattern (Sager et al., 1988: Nakanishi et al., 1992) with the presumed intersection of the anomalies near the crest of the Rise (Fig. 2). Nakanishi et al. (1989) proposed that Shatsky Rise formed by a magmatic pulse before polarity chron M20 in the Late Jurassic at a hot-spot triple-junction intersection. The subsequent flow of lava ceased at about polarity chron M12 in the Early Cretaceous.

Previous seismic-reflection and $3.5-\mathrm{kHz}$ records over Shatsky Rise show that the sediments are underlain by an undulating, presumably volcanic basement. Basement is exposed near the center of the southern plateau as a steep-sided, flat-topped seamount, apparently devoid of sediment, which reaches a depth of only $2000 \mathrm{~m}$ (Fig. 2). This seamount may thus represent the oldest exposed basement in the Pacific basin (Sliter et al., 1990) as suggested by the ages of the adjacent sediment sequence and surrounding magnetic anomalies. Evidence of younger volcanism, however, occurs on Shatsky Rise in the form of topographic features (see below) and from dredged volcanic rocks from northern Shatsky Rise dated by Ozima et al. (1970) that yield a minimum age of $56.7 \mathrm{~m} . \mathrm{y}$. from the least altered material.

Pelagic sedimentation on Shatsky Rise has been generally continuous since at least the Early Cretaceous and shows a moderately stratified section overlying the acoustic basement. Within this section, two discrete acoustic reflectors were observed to be associated with chert intervals in the mid-Cretaceous based on sediments recovered from Leg 32 (Larson, Moberly, et al., 1975). Here we argue that these reflectors are actually unconformities caused by mid-Cretaceous global climatic events associated with widespread episodes of organiccarbon deposition. Quaternary or younger channeling and slumping of the surface sediment is evident on the $3.5-\mathrm{kHz}$ records, and in some areas Lower Cretaceous sediment crops out at the seafloor.

\section{SEISMIC-STRATIGRAPHIC CORRELATIONS}

We interpret the sedimentary history of Shatsky Plateau by means of a seismic stratigraphy based on the synthesis of past profiles correlated with drilling results, primarily those of DSDP Leg 32 . The seismic stratigraphy is particularly well documented in two profiles; Vema 3612 profiler record that crosses the prominent basement high near the center of the plateau (Fig. 3), and Vema 2110 along the southeastern margin of the plateau. Here we describe the two records 


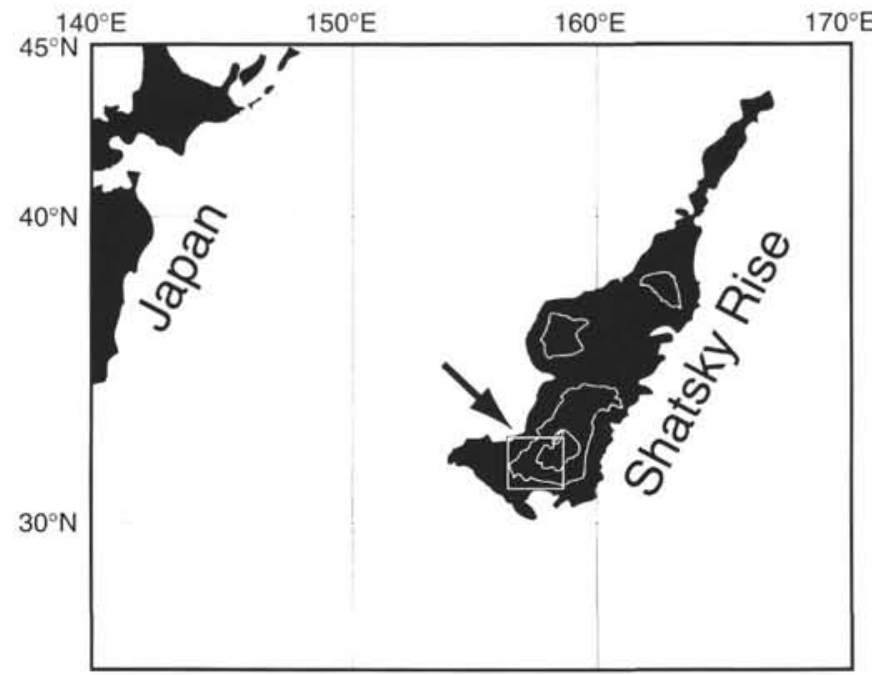

Figure 1. Location of Shatsky Rise in the western Pacific Ocean and distribution of the three prominent topographic highs. Outlined region at arrow shows the area of DSDP and ODP drilling on the southern high, Shatsky Plateau. Black outline at $5000 \mathrm{~m}$; contour interval is $1000 \mathrm{~m}$.

and use the resultant scheme to interpret the seismic stratigraphy at Site 810 and in additional seismic lines from north and south Shatsky Rise.

The Vema 3612 line shows a five-part seismic section that is typical of Shatsky Plateau adjacent to the basement high (Figs. 4A and $4 B$ ). We refer to these parts as seismic units 1 to 5 . In other sections, the characteristics of the seismic units at the margins resemble those of the unobstructed eastern flank in Figure 4. The sonic velocities used to calculate the thicknesses of the seismic units reported herein are based on the physical properties of the sediments recovered during drilling. These velocities average $1.7 \mathrm{~km} / \mathrm{s}$ for seismic unit $1,2.0 \mathrm{~km} / \mathrm{s}$ for seismic unit $2,2.2 \mathrm{~km} / \mathrm{s}$ for seismic unit $3,2.4 \mathrm{~km} / \mathrm{s}$ for seismic unit 4 , and $2.6 \mathrm{~km} / \mathrm{s}$ for seismic unit 5 . It is realized that these internal velocities apply to a "standard" section and that they may vary with thickness of the overlying section.

Seismic unit 1 consists of strong, parallel reflectors that drape over and truncate lower seismic units along the eastern margin, and onlap the upper prominent reflector (R1) at the western margin adjacent to the basement high. The thickness of seismic unit 1 is relatively uniform even on the flanks of the rise above the carbonate compensation depth (CCD) with the maximum thickness shown in Figure 4A of 64 m. A narrow transparent interval with weak reflectors separates seismic unit 1 from seismic unit 2 , and the boundary is placed beneath this interval. Seismic unit 2 consists of another packet of strong, parallel reflectors that are truncated by seismic unit 1 on the eastern margin and onlap reflector R1 on the west. The lower boundary of seismic unit 2 is placed at an angular unconformity and the maximum thickness in Figure 4A is $80 \mathrm{~m}$. Again, this unit is relatively uniform in thickness but subparallel to the seafloor.

Seismic unit 3 is composed of weak, generally parallel, undulating reflectors that form a semitransparent sequence that extends downward to the strong reflectors of reflector R 1 . The unit characteristically is lens shaped and truncated at the margins by the overlying seismic units. Seismic unit 3 , thus, is the most variable in thickness and internal characteristics of the five seismic units and reaches its maximum thickness, $286 \mathrm{~m}$, at the center of the sedimentary cap.

Seismic units 4 and 5 are similar in several respects. Both begin with the abrupt appearance of strong, parallel reflectors (i.e., R1 and R2) that grade downward into a sequence of parallel but weaker reflectors, both are similar in thickness in the center of the sedimentary caps with the maximum thickness shown in Figure 4A of 300 and $390 \mathrm{~m}$, respectively, and both thin toward the eastern margin. Still,

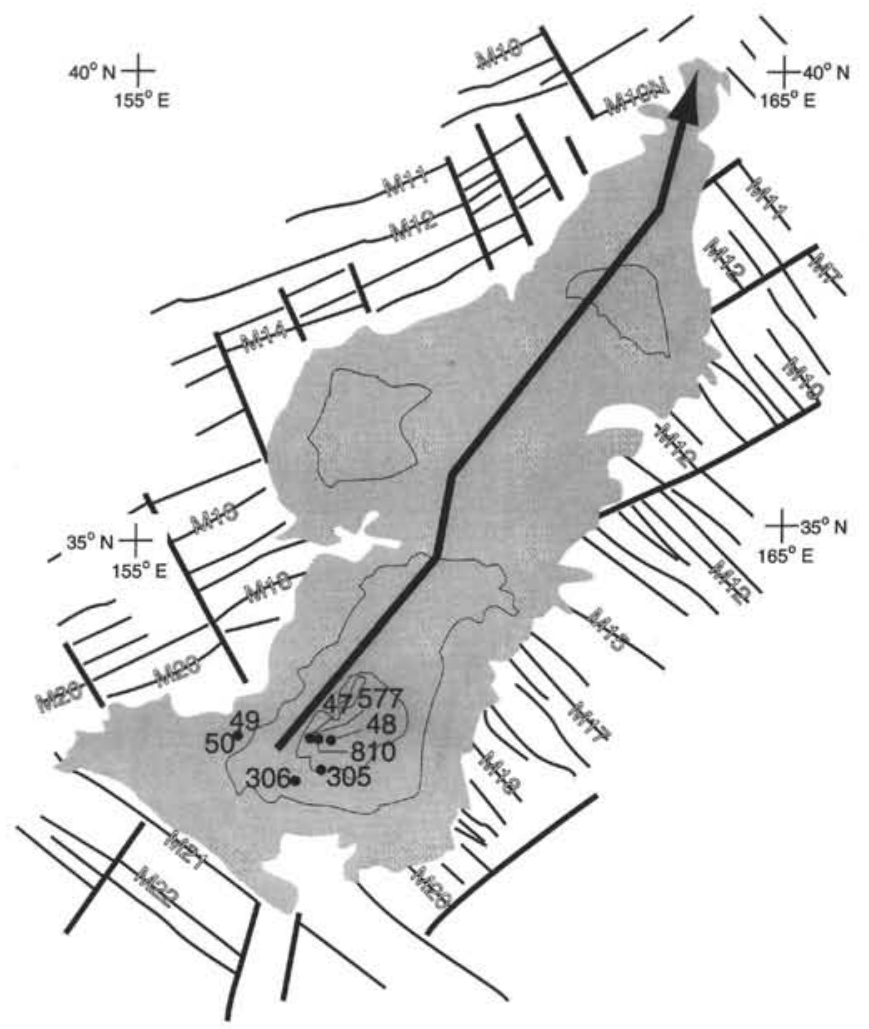

Figure 2. The orthogonal magnetic lineations identified by Nakanishi et al. (1989). The medial arrow marks the presumed path of the middle Mesozoic Pacific-Farallon-Izanagi triple junction as proposed by Nakanishi et al. (1992). Locations of DSDP and ODP drill sites on Shatsky Plateau are labeled. Shown are the three prominent highs along the northeast axis of the rise. Shaded outline at $5000 \mathrm{~m}$; contour interval is $1000 \mathrm{~m}$.

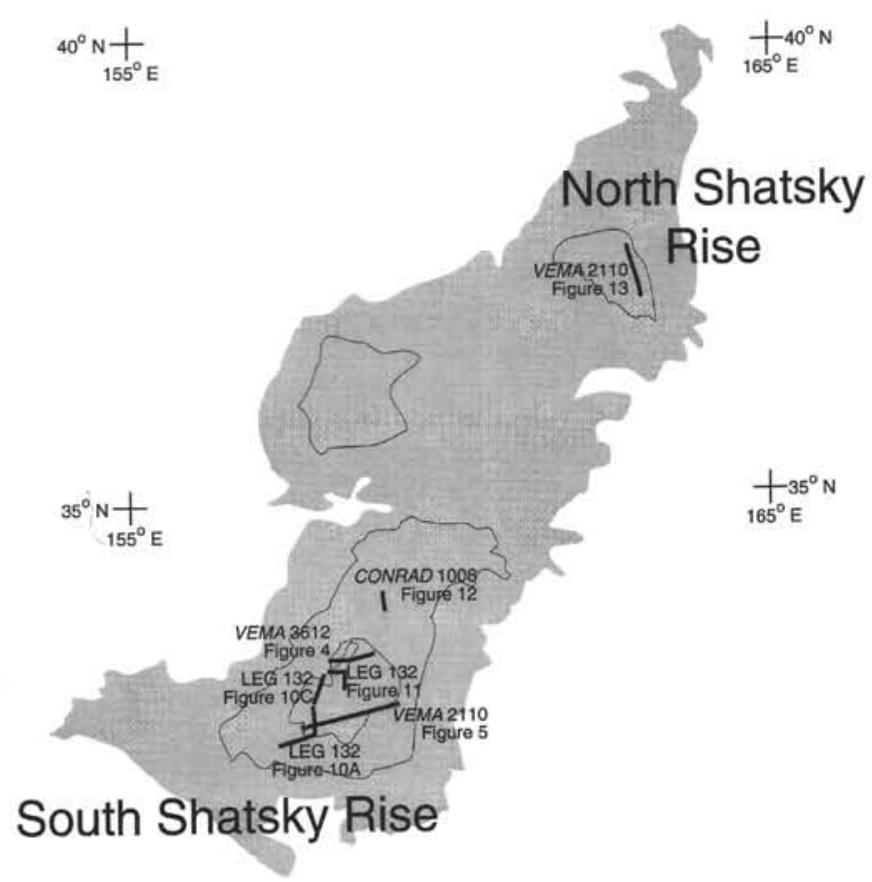

Figure 3. Approximate location of selected seismic lines from Shatsky Plateau and north Shatsky Rise discussed herein. Contour interval is $1000 \mathrm{~m}$. 


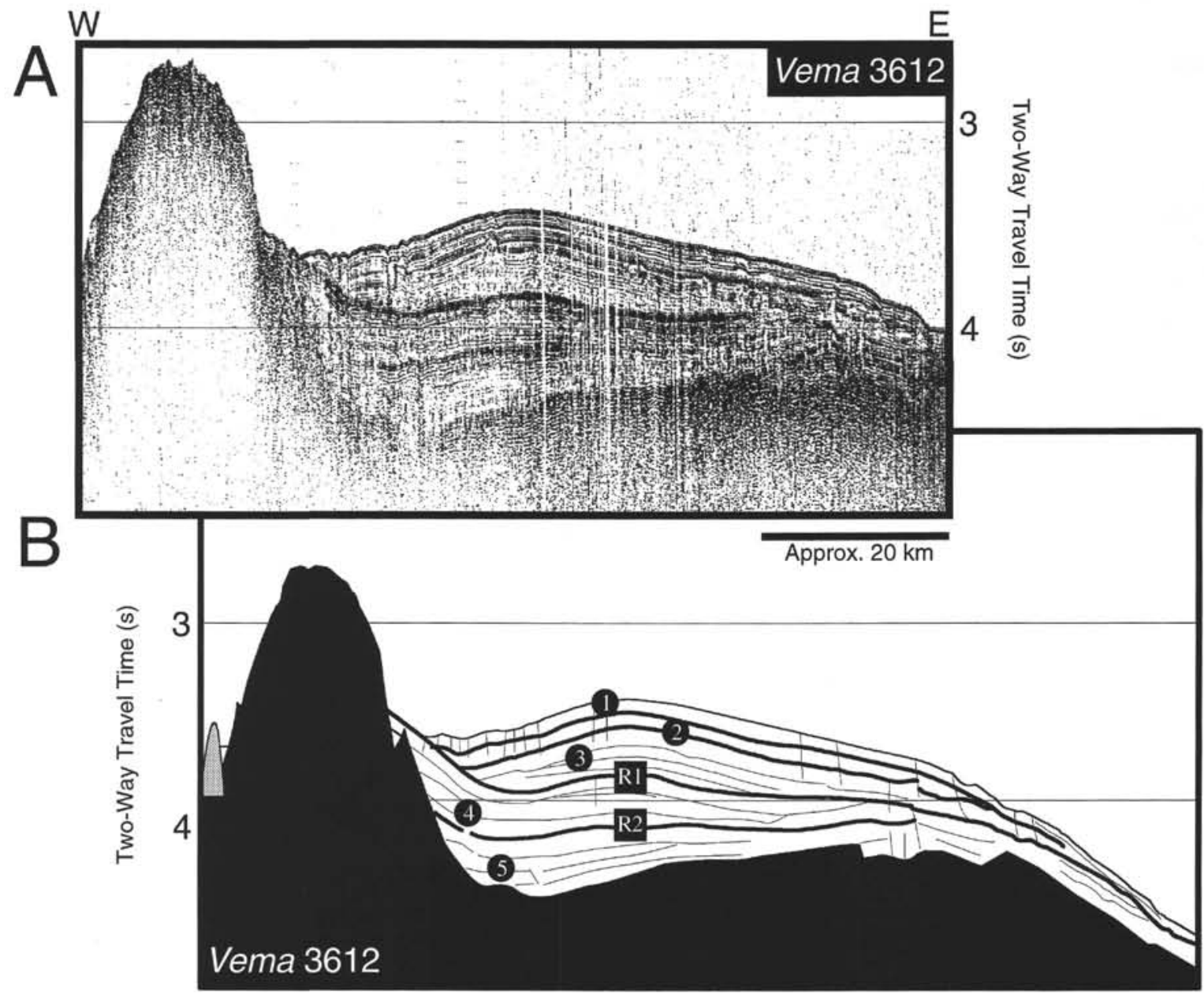

Figure 4. A. Vema 3612 profile across the prominent basement high and adjacent pelagic cap near the central portion of Shatsky Plateau (see Fig. 3 for location). B. Tracing of (A) showing the five-part seismic section typical of the sediments from Shatsky Rise, labeled seismic units 1 through 5 and reflectors R1 and R2. Notice the distinct truncation of seismic units 1 through 3 along reflector R1. The elevated hyperbolic reflection shown in gray at the lefthand margin is thought to be a post-erosional volcano.

there are subtle differences between the two units. Reflector R1 at the top of seismic unit 4 usually is more prominent and shows distinct onlapping reflectors, erosional truncation and apparent channeling on its surface. In contrast, reflector R2 is bounded mostly by apparently parallel reflectors but occasionally exhibits onlapping reflectors in steeply dipping sequences. Both reflectors R1 and R2 show some internal complexities or double reflectors; however, these are more commonly associated with reflector $\mathrm{R} 2$. In addition, the internal reflectors of seismic unit 5 are mostly weaker than those of seismic unit 4 and the intervening layers are characteristically more transparent.

The Vema 2110 profile record in Figure 5 again clearly shows the five-fold scheme and the lateral character of the seismic units. Seismic unit 1 with strong, parallel reflectors drapes over the sediment cap with a maximum thickness of about $75 \mathrm{~m}$. Seismic unit 2 is much reduced and confined to the central portion of the cap. The thickness reaches $80 \mathrm{~m}$ and the unit is truncated on both flanks by seismic unit 1 . The undulating, semitransparent reflectors and lens shape of seismic unit 3 are well documented in Figure 5 and the unit reaches a maximum thickness of $385 \mathrm{~m}$. Reflectors along the top and sides of the unit are truncated by seismic unit 1 . Reflectors $\mathrm{R} 1$ and $\mathrm{R} 2$ are visible with internal complexities or double reflectors occurring sporadically at both levels. Seismic units 4 and 5 are relatively uniform in thickness at 280 and $400 \mathrm{~m}$, respectively, and in general conform to the basement topography. Both units show slumping at the margins.

\section{Drilling Results}

The bathymetric position of drill sites from DSDP Legs 6, 32, and 86 and ODP Leg 132 on Shatsky Plateau is shown in Figure 6 and lithologic and biostratigraphic results are shown in Figure 7. Prominent unconformities characterize the mid-Cretaceous and Cenozoic sequences and chert is ubiquitous in the Cretaceous.

Sites 305 and 306 from Leg 32 represent the most complete record for interpreting our seismic stratigraphy from Shatsky Plateau. The Paleogene/Neogene unconformity typically found between $50 \mathrm{~m}$ and $65 \mathrm{~m}$ below seafloor ( $\mathrm{mbsf}$ ) is correlated with the unconformity at the base of seismic unit 1. Physical properties data from Site 577 such as shear strength, water content, bulk density, and compressional-wave velocity all show a major discontinuity at this horizon. The strength of the discontinuity suggests that the unconformity may have represented a nondepositional or erosional surface on the seafloor.

The source for the reflectors between seismic units 2 and 3 is unclear. The boundary appears to be below the Paleogene and Cretaceous/Tertiary boundary unconformities, and their associated lithologic changes, but above the prominent chert layers of the Santonian. A likely candidate for the reflectors may be the first extensive chalk layers that are well documented in the middle Maastrichtian section at Site 305.

Reflectors R1 and R2 are better correlated based on the results from Sites 305 and 306 (Fig. 8). The erosional surface at the top of 


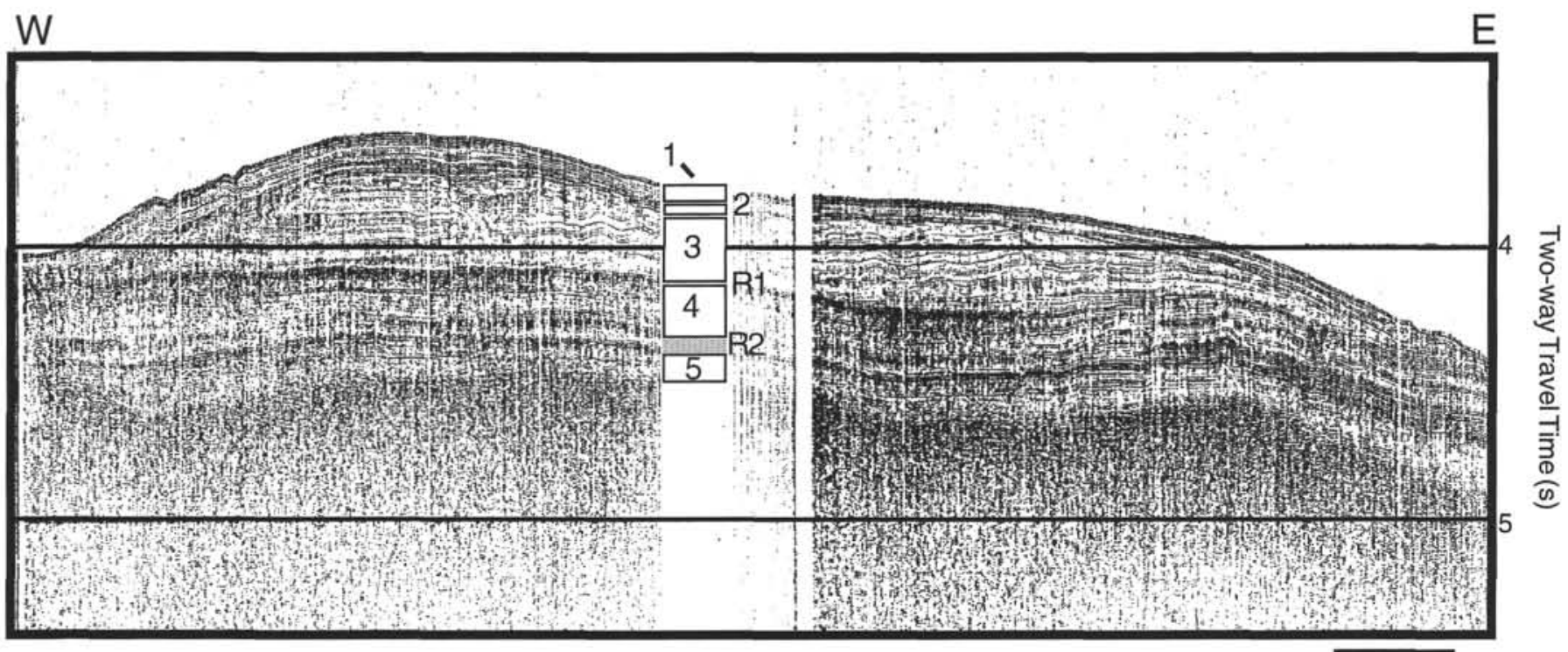

Approx. $20 \mathrm{~km}$

Figure 5. Vema 2110 single-channel seismic-reflection line across the southern flank of Shatsky Plateau showing the limited extent of seismic unit 2, lens-shaped seismic unit 3 characterized by undulating reflectors, the multiple character of reflectors R1 and R2, the relatively uniform thicknesses of seismic units 4 and 5 , and seismic unit 1 truncating the older units on the flanks (see Fig. 3 for location).

reflector R1 most likely is correlated with the prominent unconformity between the lower Cenomanian and the Coniacian at about 330 mbsf at Site 305 as was suggested by Karp and Prokudin (1985). This placement is below both the first occurrence of abundant chert near $250 \mathrm{mbsf}$ and the associated dramatic loss in recovery and reduced drill rate equated to the increase in chert at about $300 \mathrm{mbsf}$. It seems likely that reflector $\mathrm{R} 1$ is more appropriately correlated to the known unconformity and accompanying changes in physical properties than to the variable interpretation of the first chert layer. The less distinct unconformity at reflector $\mathrm{R} 2$ is correlated with the noticeable decrease in drilling rate at about $600 \mathrm{mbsf}$ near the top of the porcellanite and chert sequence as reported on Leg 132. This placement is at or near the Barremian/Aptian boundary.

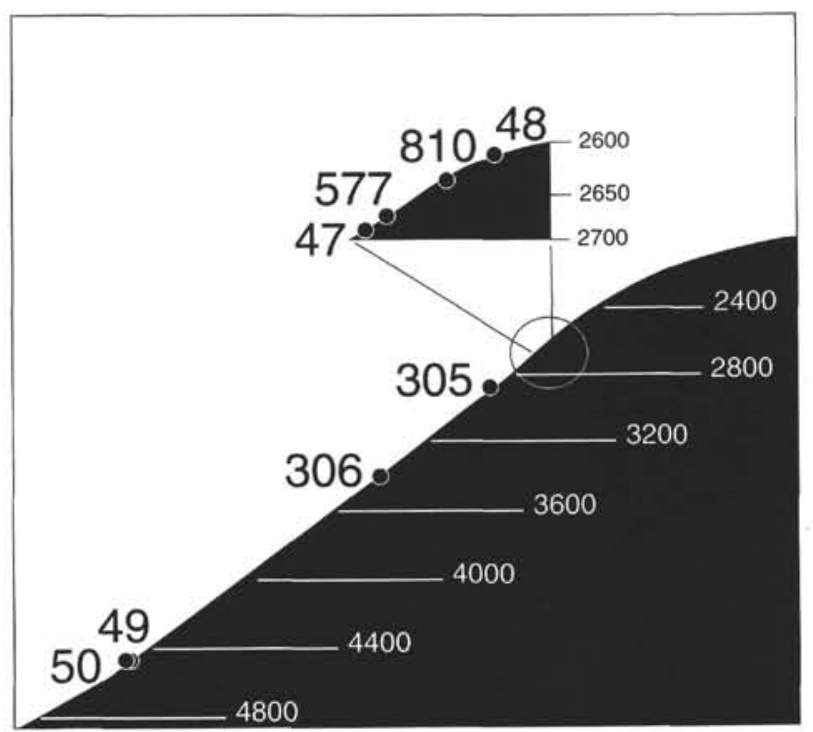

Figure 6. Schematic bathymetric profile of Shatsky Plateau and locations of Site 810 and previous DSDP drill sites on Shatsky Plateau.
Berriasian nannofossils date the oldest samples recovered from Shatsky Rise from the bottom of Site 306. Based on an early Berriasian age of about $143 \mathrm{Ma}$ (Harland et al., 1982) and a constant drilling rate to basement estimated to be at about $530 \mathrm{mbsf}$ at this site, the age of the oldest sediments would be about $150 \mathrm{Ma}$ or equivalent to Late Jurassic (Tithonian) polarity chron M21, as suggested by Nakanishi et al. (1989).

\section{LEG 132 SEISMIC-REFLECTION DATA}

Site 810 , located at latitude $32^{\circ} 25.40^{\prime} \mathrm{N}$, longitude $157^{\circ} 50.74^{\prime} \mathrm{E}$, at a water depth of $2364 \mathrm{~m}$, was occupied to field test DCS coring in chert-rich mid-Cretaceous sediment known to occur between and below the two prominent reflectors in the pelagic cap atop Shatsky Rise. The site was targeted on a Kana Keoki profiler record that showed the upper "chert reflector" could be reached with only $150 \mathrm{~m}$ of drilling. Thus, we approached Site 810 after first passing over Sites 306 and 305 as shown in Figure 9 to follow the basement and "chert reflectors" R1 and R2 within a sediment cap that thickens to the north of Site 306 but then thins at Site 810 where the sediment overlying R1 is only 0.07 s thick (Figs. 10A and 10B).

The JOIDES Resolution profiler record at Site 810 , positioned on a flat area between two channels carved by one or more erosional events, exhibits at least a four-part seismic stratigraphy that is correlated using our scheme and the paleontologic data from Leg 132 (Fig. 10C). Recognition of the complete five-part sequence typical of Shatsky Plateau is complicated both by the quality of the seismic profile from Leg 132 and by complexities in the sedimentary sequence. The uppermost part consists mostly of strong, parallel reflectors down to about 85 mbsf where a discontinuous, thin acoustically transparent layer separates the upper part from the underlying part. Part two is composed of a divergent and undulating set of subparallel, weak reflectors that thin toward the slope. The upper boundary of part two is an angular unconformity that continues downslope until part one appears to rest on part three. The lower boundary of part two is placed at $110 \mathrm{mbsf}$ at the first recording of a set of strong, parallel to subparallel reflectors corresponding to reflector R1. The top of part three corresponds to a set of strong reflectors that show evidence of 


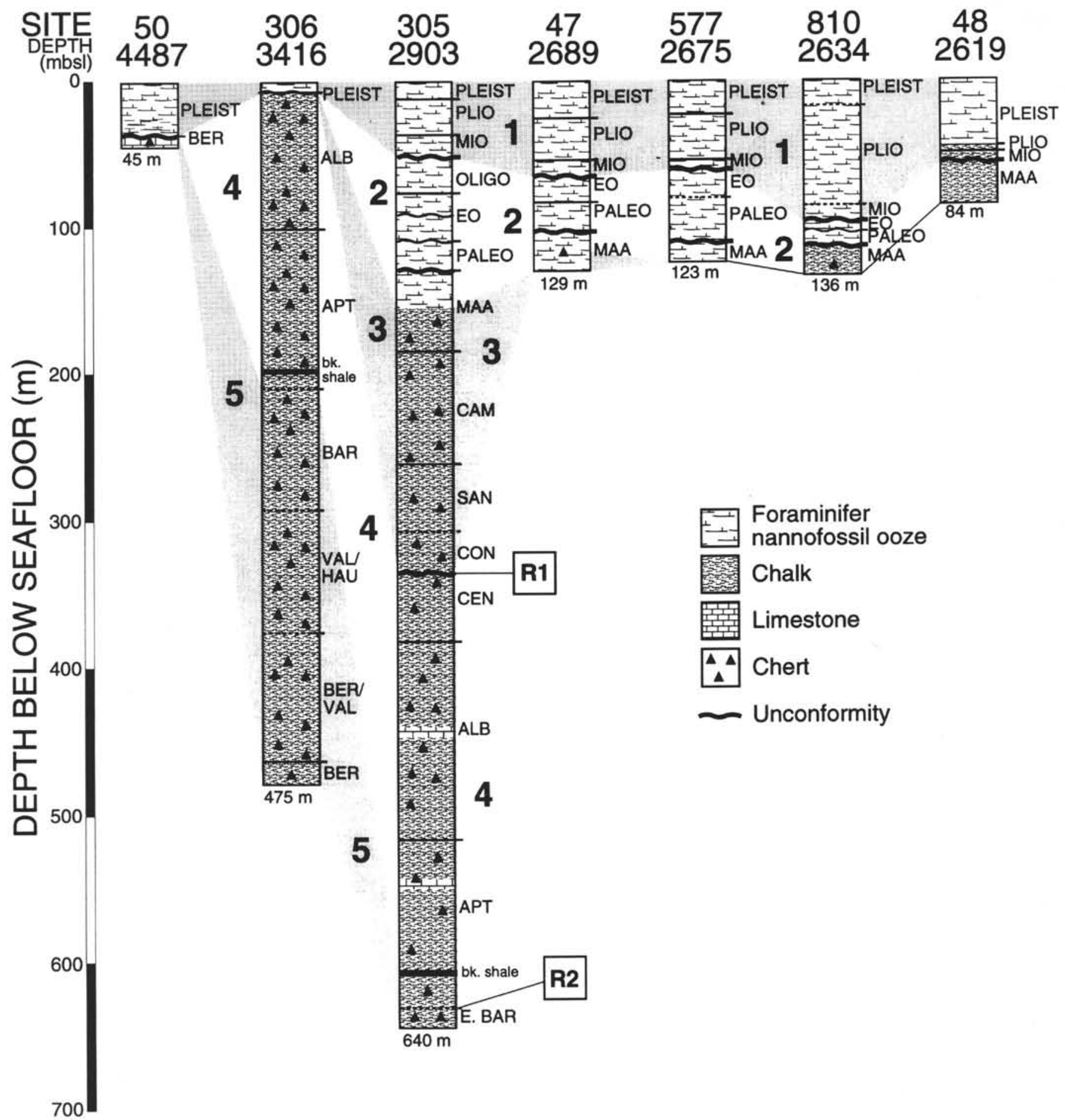

Figure 7. Lithologic columns from Site 810 and previous DSDP drill sites on Shatsky Plateau showing age, lithology, lithologic thicknesses, prominent unconformities, and identification of seismic units 1 to 5 . Correlation of seismic units between sites is shaded. Pleist $=$ Pleistocene, Plio $=$ Pliocene, Mio $=$ Miocene, Oligo $=$ Oligocene, $\mathrm{Eo}=$ Eocene, Paleo $=$ Paleocene, $\mathrm{Maa}=$ Maastrichtian, $\mathrm{Cam}=\mathrm{Campanian}, \mathrm{San}=\mathrm{Santonian}, \mathrm{Con}=\mathrm{Coniacian}, \mathrm{Cen}=\mathrm{Cenomanian}, \mathrm{Alb}=$ Albian, $\mathrm{Apt}=$ Aptian, $\mathrm{Bar}=$ Barremian, Hau $=$ Hauterivian, $\mathrm{Val}=$ Valanginian, $\mathrm{Ber}=$ Berriasian, $\mathrm{E}=$ early .

seafloor erosion and channeling. With depth, part three is an acoustically nonreflective or generally transparent section exhibiting weak, mostly continuous reflectors. A band or packet of parallel reflectors at 215 mbsf represents "reflector" R2 that marks the top of part four. Part four consists mostly of weak parallel reflectors that extends downward to the next strong reflectors at $601 \mathrm{mbsf}$ that probably represents volcanic basement.
The boundary between parts one and two represents the Paleogene/Neogene unconformity dated near 100 mbsf by Premoli Silva et al. (this volume). As at Site 577, a noticeable change in physical properties occurs at this unconformity including a significant decrease in magnetic susceptibility and a sharp increase in compressional wave velocity. Part one thus is equivalent to seismic unit 1 and the thickened Neogene sequence (see Fig. 7) may be related to 


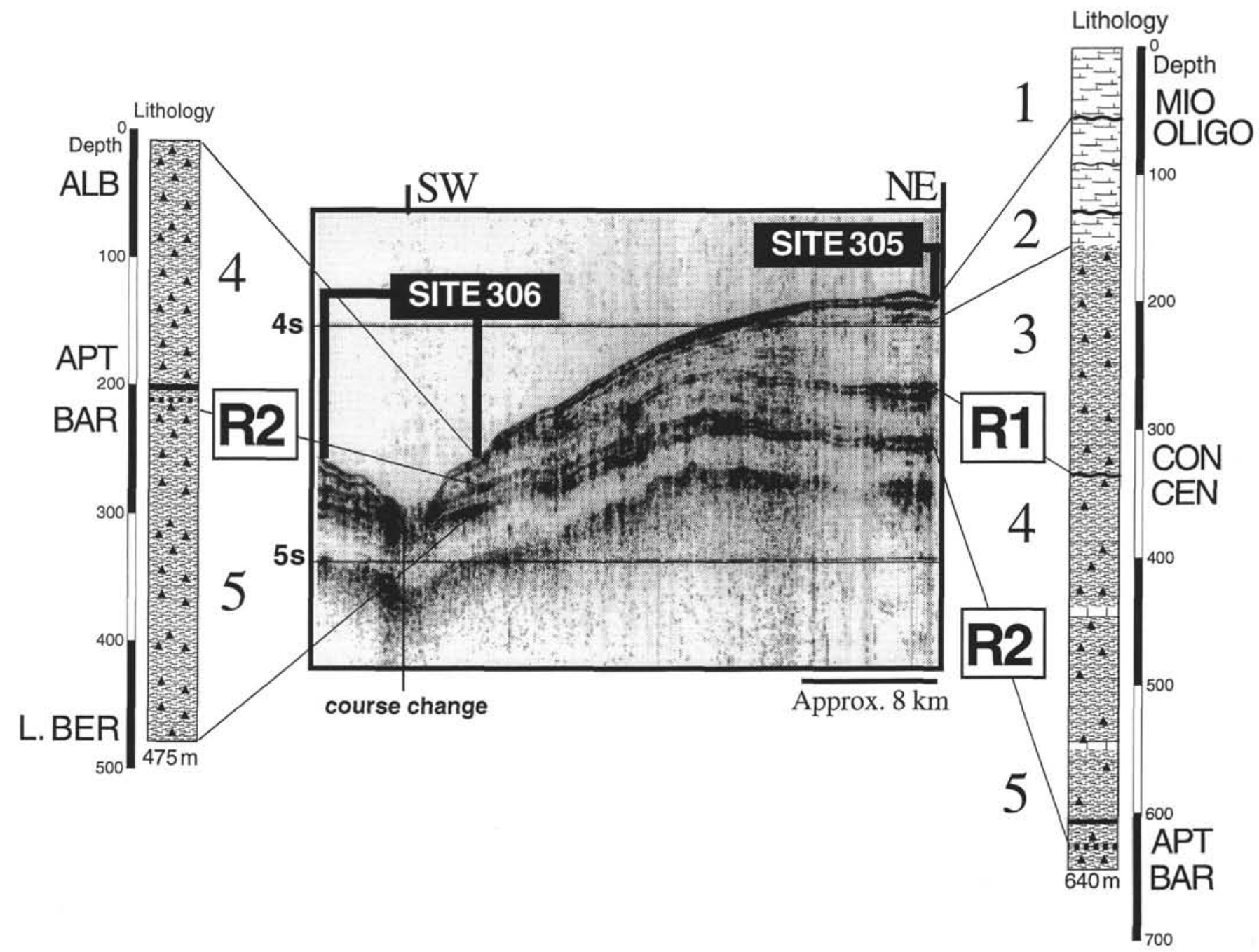

Figure 8. Age and correlation of seismic reflectors R1 and R2 at DSDP Sites 305 and 306. Also shown are prominent unconformities, generalized lithology, and identification of seismic units 1 to 5 . Lithologic symbols as in Figure 7.

downslope transport associated with the adjacent channel system. The presence of redeposited benthic foraminifers throughout the Pliocene/Pleistocene sequence and a mixture of cooler and warmer planktonic foraminifers in the Pleistocene section (Premoli Silva et al., this volume) support the transport hypothesis.

Part two with truncated, undulating, and semitransparent reflectors that extend downward to the strong reflectors of R1 at $195 \mathrm{mbsf}$ appears to include both seismic units 2 and 3. The upper half of this unit, dated as late Maastrichtian to late Eocene in age at the base of Site 810 or from about 100 to 136 mbsf (Premoli Silva et al., this volume), correlates with seismic unit 2 . Just below this depth, the more noticeably contorted reflectors in part two represent an abbreviated version of seismic unit 3. Mass wasting visible along the lower slope in Figure $10 \mathrm{C}$ at $4 \mathrm{~s}$ water depth north of Site 810 appears to be rooted in the lower half of part two. Finally, parts three and four with thicknesses of 120 and $260 \mathrm{~m}$, respectively, that occur above and below an expanded and complex version of reflector R2, correlate with seismic units 4 and 5 .

Extending the seismic stratigraphy downslope reveals differences in the internal character of the seismic units as shown in Figures $10 \mathrm{~A}$ and 10B. Seismic units 4 and 5 that lie beneath reflector R1 appear to maintain their approximate thickness until truncated at the plateau's margin with parallel internal reflectors that conform to the basement topography. In contrast, the upper units are variable in thickness. This includes the obvious expansion of seismic unit 3 as well as the apparent expansion of seismic unit 2. Both units reach a maximum thickness near Site 305 but thin up- and downslope. The diverging reflectors seen in part two at the lefthand margin of Figure 10C apparently represent the thinning of seismic unit 2 caused by the overlying unconformity. Both the thinning and lateral truncation of seismic unit 2 in this record are similar to the interpretation from the Vema 2110 record shown in Figure 5. Seismic unit 1 shows similar variations in thickness especially between Sites 305 and 810 although the differences are much less than those of seismic units 2 and 3 . In addition, all or a portion of seismic unit 1 may pinch out between Sites 306 and 305 .

Leaving Site 810 , we circled northward over the basement seamount and back along the thick sediment cap (see Fig. 9 for location) to exit the area to the southwest across Site 810 . The profiler record in Figure 11 is similar to the Vema 3612 record in Figure 4 and shows the prominent seamount faulted on the western flank and bounded on the eastern flank by the sediment cap that displays two strong internal reflectors R 1 and R2 at about 300 and 700 mbsf, respectively. Moating exhibited in both Figures 4 and 7 documents the concentration of intermediate-water currents around the base of the seamount. The reduced quality of the Leg 132 record, however, shows only a general four-part internal seismic stratigraphy compared to the five-part stratigraphy exhibited in Figure 4. Basement at the thickest part of the sediment sequence in the Leg 132 record occurs at about 1083 mbsf. 


\section{North-South Correlations}

Here we correlate our seismic scheme with selected seismic profiles from north and south Shatsky Rise (Fig. 3) to derive a better understanding of the sedimentary history across this huge structure. The profiles include Conrad 1008 across the northeastern margin of Shatsky Plateau (Fig. 12) and Vema 2110 that tracks across the northern high of Shatsky Rise (Fig. 13).

The Conrad 1008 single-channel profile (Fig. 12) at the northern flank of Shatsky Plateau shows a thinner and more complex stratigraphy than the more southern profiles. The parallel reflectors of seismic units 1 and 2 truncate the reflectors of seismic unit 3 . The boundary between seismic units 1 and 2 is not well defined but may occur in the central transparent interval that overlies a packet of stronger reflectors. The thickness of both units shown combined in Figure 12 is about $145 \mathrm{~m}$. The weak reflectors of seismic unit 3 are smoother and less undulating in this profile than in those from the central and southern parts of the plateau. This unit reaches a maximum thickness of about $340 \mathrm{~m}$ in Figure 12. The two prominent reflectors (R1 and R2) are best seen in the saddle and become diffuse over the basement complexities to the southeast and onlap the basement to the north. Seismic units 4 and 5 are noticeably thinner in this profile and both reach a maximum thickness of less than $200 \mathrm{~m}$.

The Vema 2110 single-channel profile across the northern high (Fig. 13) shows a similar but thinner and more subdued acoustic stratigraphy. Reflectors R1 and R2 are visible but difficult to discern. Seismic units 4 and 5 are equal in thickness at about $170 \mathrm{~m}$ and conform to the bottom topography. Above reflector R1 the seismic record is difficult to trace laterally. The uppermost unit is about $60 \mathrm{~m}$ thick and most likely represents a reduced combination of seismic units 1 and 2, again separated by a thin, weakly reflecting semitransparent interval. As the present record is inconclusive, however, the units are combined in Figure 13. The gently undulating reflectors of the unit above reflector Rl and below the upper grouping are correlated with seismic unit 3 . This latter unit reaches a maximum thickness of $143 \mathrm{~m}$. Thus, the record from the northern high, regardless of the unit designation, documents a major reduction in thickness of the pre-Miocene sequence.

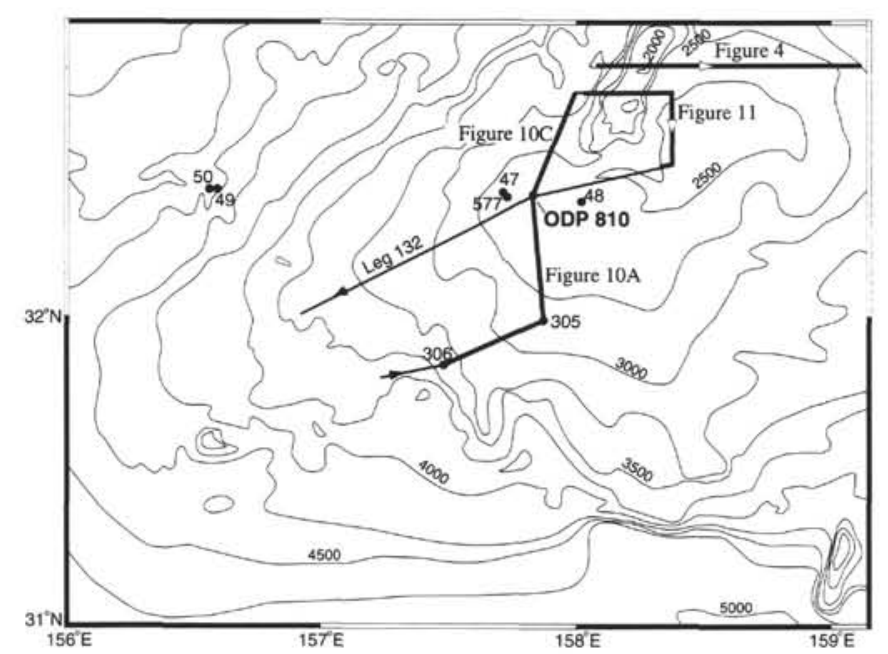

Figure 9. Track of the JOIDES Resolution Leg 132 seismic line plotted on a detailed bathymetric map of southwest Shatsky Plateau outlined by the box in Figure 1. The darker segments of the track are shown in Figures 10 and 11. The map identifies the prominent basement high and plateau summit in relation to the location of Site 810 and the previous DSDP sites. The east-west line across the summit north of the Leg 132 track is the Vema 3612 profile shown in Figure 4. Contour interval is $250 \mathrm{~m}$.

\section{CONCLUSIONS AND DISCUSSION}

The scientific accomplishments of Leg 132 include the recovery of a Cenozoic to Upper Cretaceous section at Site 810 located on the southwest flank of Shatsky Plateau and a new seismic profile across the summit. Analysis of the profile and previous seismic records shows that the sedimentary stack atop much of Shatsky Rise can be divided into five seismic units. Previous drilling on the southern plateau and the internal characteristics of the seismic units provides the basis for interpreting the sedimentary history of the rise and the paleoceanography of the Pacific Ocean since the Early Cretaceous.

The five-part division we use differs somewhat from previous analyses of the same sedimentary sequence as follows. The five-part division identified at Site 577 of Leg 86 (Heath, Burkle, et al., 1985) includes our seismic units 1 and 2 in their unit 1 , parts of our seismic units 2 to 4 in their units 2 and 3 , and our seismic unit 5 in their units 4 and 5. In the four-part schemes of Karp and Prokudin (1985) and Khankishiyeva (1989), our seismic units 1 and 2 equal their uppermost unit, our seismic unit 3 equals their second unit, our seismic unit 4 equals their third, and our seismic unit 5 equals their fourth. Regardless of the differences between the various schemes, the individual characteristics of the seismic units are remarkably consistent throughout the length of Shatsky Rise. Consequently, we have used the long-distance seismic correlations as a tool in making the following paleoceanographic interpretations.

\section{Paleogeography}

Several lines of evidence suggest that of Shatsky Rise formed in the Southern Hemisphere. These include the thickness and character of the sedimentary cap that identify passage of the high beneath the highly productive equatorial divergence resulting from the motion of the oceanic plate (e.g., Lancelot, 1978; Lancelot and Larson, 1975). In addition, calculations using the apparent polar wander path of Gordon (1990) place Shatsky Rise at about $5^{\circ} \mathrm{S}$ during the Aptian. Our conclusions agree with and expand upon these results.

Accordingly, we believe the parallel reflectors and similar thicknesses of the lowermost, silica-rich seismic units 5 and 4 record uniform sedimentation rates and subsequent compaction and diagenesis in the Mesozoic Pacific south of the equatorial divergence. Thinning of the units on the flanks and the slumping at the margin seen, for example, in Figure 4A, indicate that Shatsky Rise was a positive feature at least in the Early Cretaceous. Indeed, benthic foraminifers described by Douglas (1971) from Lower Cretaceous sediments at DSDP Sites 49 and 50 are indicative of intermediate, bathyal water depths above the CCD.

The thick, lens-shaped seismic unit 3 consisting of mostly Coniacian to Campanian age is characterized by weak, undulating reflectors that indicate passage beneath the equatorial divergence. The smoothing of the reflectors in this unit to the north (Figs. 12 and 13) suggests that the southern plateau was more directly beneath the divergence at this time. We attribute the undulating character and weakness of the reflectors in this unit to differential compaction amplified by sediment loading of the rapidly deposited, fluid-rich sediment. Subsequent dewatering may have contributed to the disruption of the reflectors. Marginal slumping reaches a maximum in this unit and contributes to our interpretation of a fluid-rich unit with mass wasting perhaps accentuated by differential diagenesis especially during the Coniacian to Santonian in the Pacific Ocean (Thierstein, 1979).

The even, parallel reflectors in seismic unit 2 of Maastrichtian to Oligocene age indicate deposition north of the divergence. Cretaceous benthic foraminifers from Site 810 (Storms, Natland, et al., 1991), that include Aragonia, suggest that the southern plateau may have subsided to deeper bathyal water depths by the Maastrichtian. The uniform thickness of the Neogene cap (i.e., seismic unit 1), along the length of the rise, given the thinning of the other seismic units, 

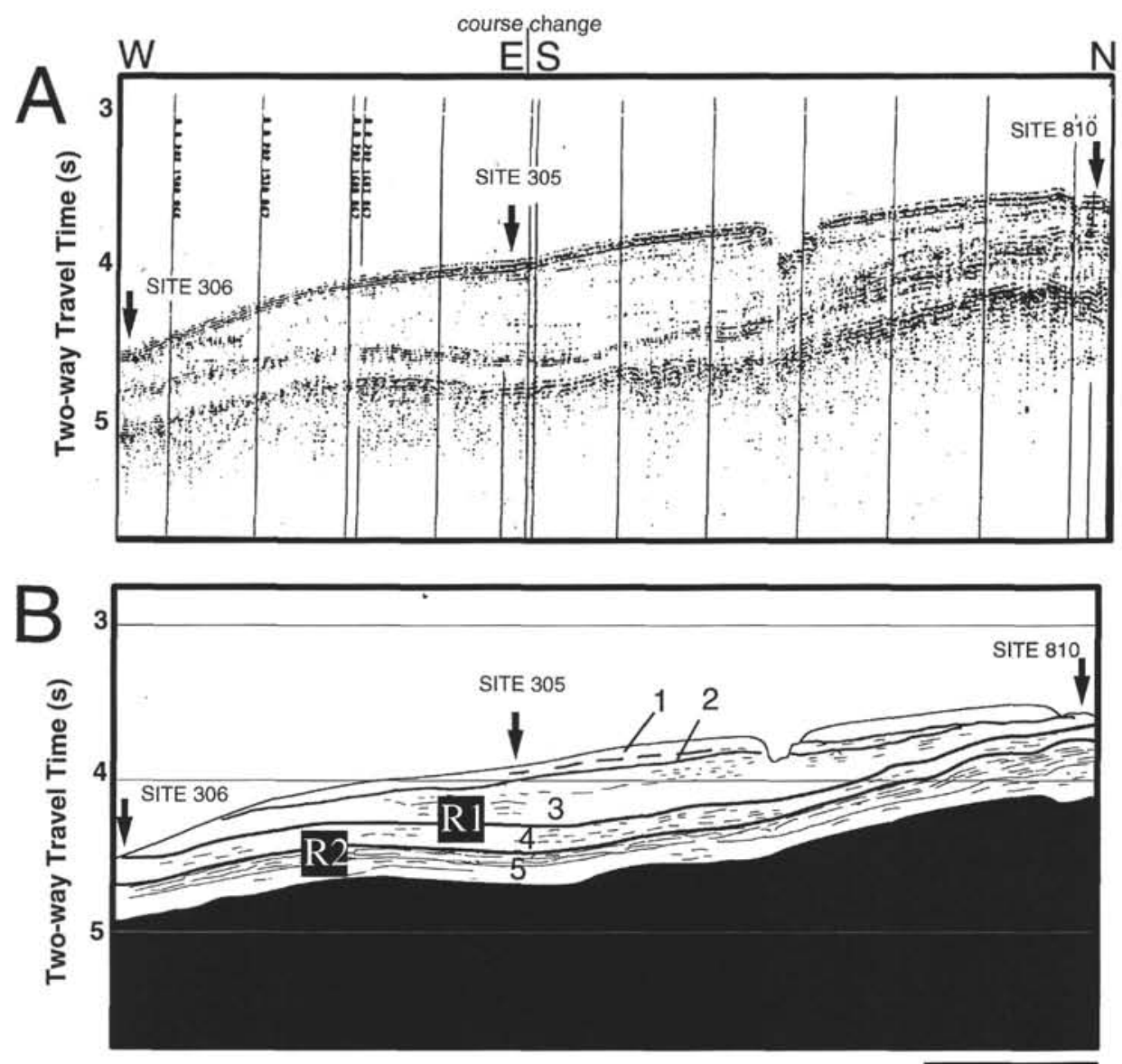

Approx. $16 \mathrm{~km}$

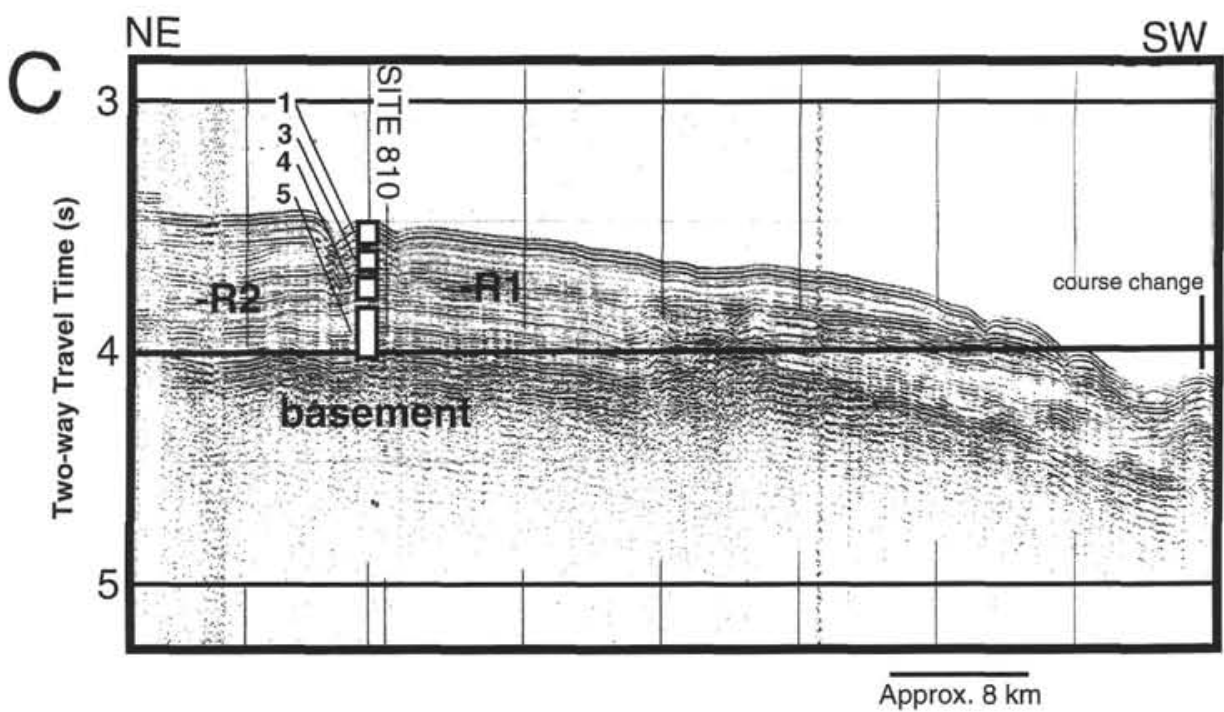

Figure 10. A. Unprocessed single-channel seismic-reflection profile from JOIDES Resolution Leg 132 taken during the approach to Site 810 after passing over DSDP Sites 306 and 305 (see location in Fig. 9) that shows surface channeling and seismic stratigraphy. B. Tracing of Figure 5A showing location of Sites 306, 305, and 810 , prominent reflectors $\mathrm{R} 1$ and $\mathrm{R} 2$, and the limited internal stratigraphy visible in this profile. $\mathrm{C}$. Enlargement of the profile at Site 810, located between two surface channels, showing the limited internal seismic stratigraphy visible in this profile. 


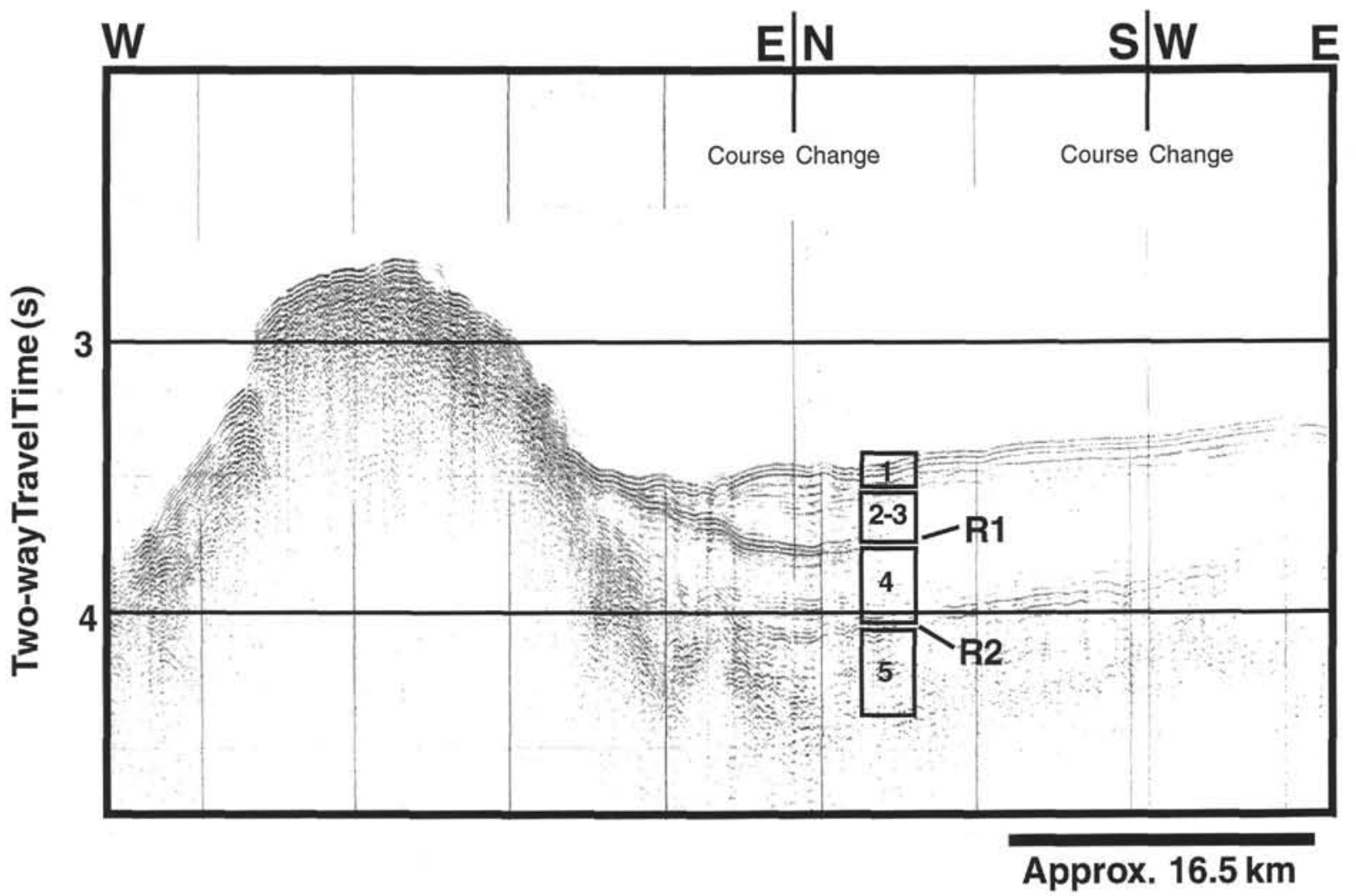

Figure 11. Unprocessed single-channel seismic-reflection profile from JOIDES Resolution Leg 132. The profile represents the portion of track shown in Figure 9 that progresses east across the prominent basement high, and then south and southwest across the adjacent sedimentary cap toward Site 810 . This record shows the strong reflectors R1 and R2 and a limited internal seismic stratigraphy.

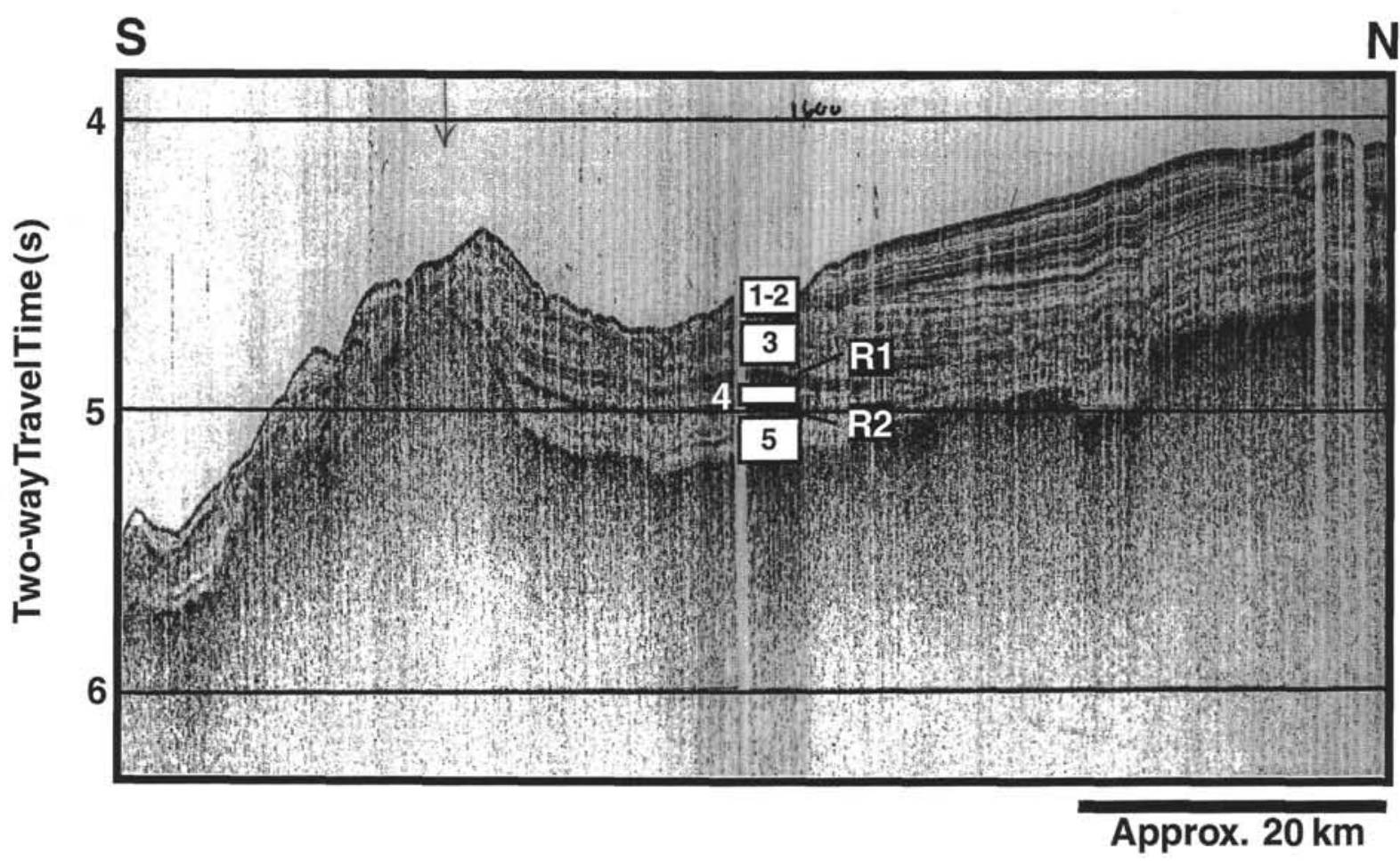

Figure 12. Conrad 1008 single-channel seismic line across the northern flank of Shatsky Plateau (see Fig. 3 for location) showing reflectors $\mathrm{R} 1$ and R2 in the saddle and smoother reflectors in seismic unit 3 beneath combined seismic units 1 and 2 than in profiles to the south. The reduced sedimentary section over the northern flank perhaps reflects current scour or lowered sedimentation rates. 


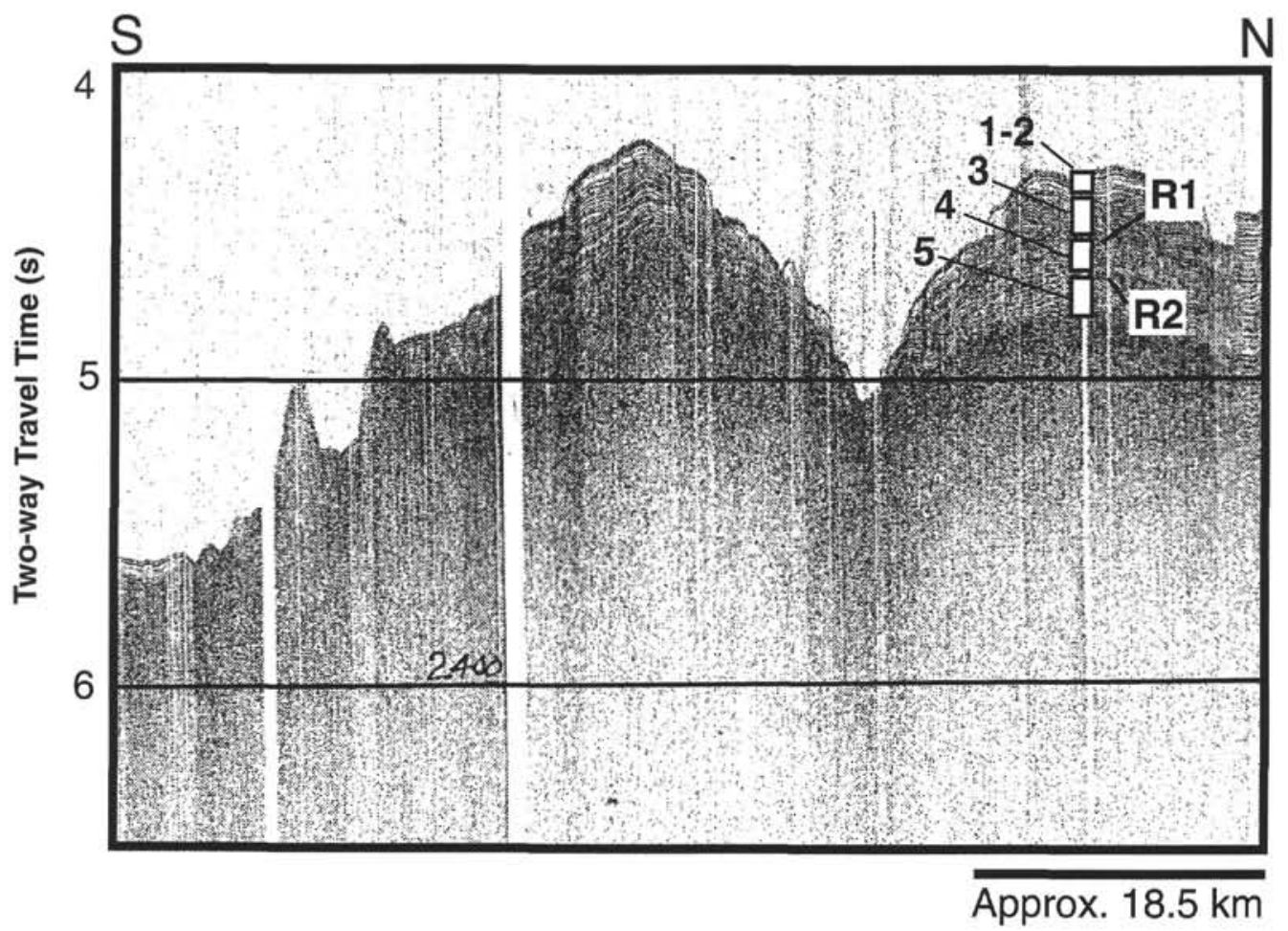

Figure 13. Vema 2110 single-channel seismic profile across the northern high of Shatsky Rise showing weak reflectors $\mathrm{R} 1$ and R2 and the greatly reduced thickness of seismic units 3 to 5 beneath combined seismic units 1 and 2 (see Fig. 3 for location).

indicates a more central paleoceanographic position with slow but persistent sedimentation over a wide area during the Neogene.

\section{Unconformities}

Of particular interest are the unconformities that represent changes in the physical and chemical character of the water column, and hence, biologic productivity. In addition to the obvious unconformities at the Cenomanian/Coniacian and Paleogene/Neogene boundaries, we also include in our stratigraphy the unconformity at the lithologic change from chalk and chert to well-lithified chert and porcellanite near the Barremian/Aptian boundary represented by reflector R2. The two younger unconformities are both associated with changes in physical properties as well as erosional events. These events are evidence by the channeled surface of reflector R1 and the onlapping younger seismic units (see Figs. 4 and 11) and by the reworked Cretaceous and Paleogene foraminifers in the basal Neogene sediments (Premoli Silva et al., this volume).

The lithologic change at the Barremian/Aptian boundary likewise is associated with an erosional event, as evidenced by the occasional onlapping of younger reflectors along reflector R2 that is best seen in Figure 4. Regardless, we suggest that the increase in porcellanite and chert at this depth interval is related to enhanced upwelling and productivity above the plateau which in turn led to heightened carbonate dissolution. As noted by Berger and Winterer (1974), higher rates of organic-carbon deposition owing to increased productivity lead to dissolution, especially in intervals that are carbonate poor and silica rich. Thus, both the stratigraphic and lithologic changes at reflector R2 may have resulted from mixing of the water column above the seamount during a period of increased oceanic circulation, especially at intermediate water depths. The timing of these events is especially intriguing given the close correlation to a distinct, short-term, global episode of organic-carbon deposition in the early Aptian at about 123
Ma called the Selli event (see Sliter, 1989) and the corresponding time of formation of Ontong Java Plateau in the South Pacific (Tarduno et al., 1991) with the resultant changes in ocean chemistry and rise in eustatic sea level attributed to this latter event (Larson, 1991).

How these variables would interact is best demonstrated by examining the unconformity at reflector R1 that also closely coincides with an organic carbon-rich episode, in this case, the Bonarelli event at the Cenomanian/Turonian boundary (Schlanger et al., 1987). At this better documented event, the changes are related to a maximum sea-level highstand, an increase in deep-water upwelling, and accompanying peaks in sea-surface fertility and productivity (Arthur et al., 1987). In this case also, we believe that the lithologic changes associated with reflector R1, as those at reflector R2, resulted from the higher rate of organic carbon deposition. In addition, we relate the pronounced erosional event at reflector $\mathrm{R} 1$ to heightened circulation and current scouring at intermediate water depths caused by the influx of warm, saline water derived from flooded ocean-margin areas (Brass et al., 1982). Thus, the link between density-driven oceanic circulation and an erosional event at this boundary within the Pacific basin as proposed by Sliter (1991) may also apply to the earlier erosional event at reflector R2.

The Paleogene/Neogene unconformity, identified on Shatsky Rise by the DSDP (Fischer, Heezen, et al., 1971; Pimm, 1972) and typically represented by a middle Eocene to late Miocene hiatus, may involve multiple Paleogene unconformities. The recovery of lower Miocene sediments overlying the upper Oligocene at Site 305 (Fig. 7), however, identifies an unconformity that closely coincides with the opening of the Drake Passage (Kennett, 1977) and the establishment of the deep circumpolar current. This event that led to increased global cooling, intensified circulation, and a major faunal turnover is associated with widespread hiatus PH of Keller and Barron (1983) and thus may have been the major contributor to the Paleogene/Neogene unconformity on Shatsky Rise. 


\section{ACKNOWLEDGMENTS}

We thank the Ocean Drilling Program for encouraging the scientific component to Leg 132. The return to Shatsky Rise made it clear that much more work is needed on the plateau to reveal the processes and history of global climate change in the Cretaceous. We are especially grateful to J. Natland for focusing the scientific accomplishments during the leg, for helping design and carry out the geophysical survey, for providing post-cruise monetary support and encouragement of the present collaboration, and for reviewing an early version of this paper. We thank J. Barron, R. Larson, W. Sager, and D. Scholl for the helpful reviews of the manuscript. In addition, we acknowledge B. Damjanovic and E.V. Kohnen for assisting in the preparation of the paper and S. Lewis for thoughts on seismic interpretation. Glenn Brown's participation on Leg 132 was funded by the Scotiabank Marine Geology Research Laboratory, University of Toronto.

\section{REFERENCES ${ }^{*}$}

Arthur, M.A., Schlanger, S.O., and Jenkyns, H.C., 1987. The CenomanianTuronian oceanic anoxic event, II. Palaeoceanographic controls on organic-matter production and preservation. In Brooks, J., and Fleet, A.J. (Eds.), Marine Petroleum Source Rocks. Geol. Soc. Spec. Publ. London, 26:401-420.

Berger, W.H., and Winterer, E.L., 1974. Plate stratigraphy and the fluctuating carbonate line. In Hsü, K.J., and Jenkyns, H.C. (Eds.), Pelagic Sediments on Land and Under the Sea. Spec. Publ. Int. Assoc. Sedimentol., 1:11-48.

Brass, G.W., Southam, J.R., and Peterson, W.H., 1982. Warm saline bottom water in the ancient ocean. Nature, 296:620-623.

Douglas, R.G., 1971. Cretaceous foraminifera from the northwestern Pacific Ocean: Leg 6, Deep Sea Drilling Project. In Fischer, A.G., Heezen, B.C., et al., Init. Repts. DSDP, 6: Washington (U.S. Govt. Printing Office), $1027-1053$.

Fischer, A.G., Heezen, B.C., et al., 1971. Init. Repts. DSDP, 6: Washington (U.S. Govt. Printing Office).

Gordon, R.G., 1990. Test for bias in paleomagnetically determined paleolatitudes from Pacific Plate Deep Sea Drilling Project sediments. J. Geophys. Res., 95:8397-8404.

Harland, W.B., Cox, A.V., Llewellyn, P.G., Pickton, C.A.G., Smith, D.G., and Walters, R., 1982. A Geologic Time Scale: Cambridge (Cambridge Univ. Press).

Heath, G.R., Burckle, L.H., et al., 1985. Init. Repts. DSDP, 86: Washington (U.S. Govt. Printing Office).

Karp, B.Y., and Prokudin, V.G., 1985. The structure of the sedimentary layer on the Shatsky Rise according to seismic data. Tikhookkean. Geol., 3:26-33.

Keller, G., and Barron, J.A., 1983. Paleoceanographic implications of Miocene deep-sea hiatuses. Geol. Soc. Am. Bull., 94:590-613.

Kennett, J.P., 1977. Cenozoic evolution of Antarctic glaciation, the circumAntarctic Ocean, and their impact on global paleoceanography. J. Geophys. Res., 82:3843-3860.

Khankishiyeva, L.M., 1989. The structure and seismostratigraphy of the sedimentary cover on the Shatsky Rise (Pacific Ocean). Okeanologiya, 29:178-183.
Lancelot, Y., 1978. Relations entre évolutions sédimentaire et tectonique de la plaque Pacifique depuis le Crétacé inférieur. Mem. Soc. Geol. Fr., 134.

Lancelot, Y., and Larson, R.L., 1975. Sedimentary and tectonic evolution of the northwestern Pacific. In Larson, R.L., Moberly, R., et al., Init. Repts. DSDP, 32: Washington (U.S. Govt. Printing Office), 925-939.

Larson, R.L., 1991. Geological consequences of superplumes. Geology, 19:963-966.

Larson, R.L., Moberly, R., et al., 1975. Init. Repts. DSDP, 32: Washington (U.S. Govt. Printing Office).

Nakanishi, M., Tamaki, K., and Kobayashi, K., 1992. Magnetic anomaly lineations from Late Jurassic to Early Cretaceous in the west-central Pacific Ocean. Geophys. J. Int., 109:701-719.

Ozima, M., Kaneoka, I., and Aramaki, S., 1970. K-Ar ages of submarine basalts dredged from seamounts in the western Pacific area and discussion of oceanic crust. Earth Planet. Sci. Lett., 8:237-249.

Pimm, A.C., 1972. Shatsky Rise sediments: correlation of lithology and physical properties with geologic history. AAPG Bull., 56:364-370.

Sager, W.W., Handschumacher, D.W., Hilde, T.W.C., and Bracey, D.R., 1988. Tectonic evolution of the northern Pacific Plate and Pacific-FarallonIzanagi triple junction in the Late Jurassic and Early Cretaceous (M21M10). Tectonophysics, 155:345-364.

Schlanger, S.O., Arthur, M.A., Jenkyns, H.C., and Scholle, P.A., 1987. The Cenomanian-Turonian Oceanic Anoxic Event, I. Stratigraphy and distribution of organic carbon-rich beds and the marine $\delta^{1 / 3} \mathrm{C}$ excursion. In Brooks, J., and Fleet, A.J. Marine Petroleum Source Rocks. Geol. Soc. Spec. Publ. London, 26:371-399.

Sliter, W.V., 1989. Aptian anoxia in the Pacific Basin. Geology, 17:909-912. , 1991. Cretaceous hiatuses, black shales and Pacific paleoceanography. Geol. Soc. Am., Abstr. Programs, 23:A341. (Abstract)

Sliter, W.V., van Waasbergen, R.J., Brown, G.R., and ODP Leg 132 Scientific Party, 1990. Tectonic and stratigraphic evolution of Shatsky Rise. Eos, $71: 1673$.

Storms, M.A., Natland, J.H., et al., 1991. Proc. ODP, Init. Repts., 132: College Station, TX (Ocean Drilling Program).

Tarduno, J.A., Sliter, W.V., Kroenke, L., Leckie, M., Mayer, H., Mahoney, J.J., Musgrave, R., Storey, M., and Winterer, E.L., 1991. Rapid formation of Ontong Java Plateau by Aptian mantle plume volcanism. Science, 254:399-403.

Thierstein, H.R., 1979. Paleoceanographic implications of organic carbon and carbonate distribution in Mesozoic deep sea sediments. In Talwani, M., Hay, W., and Ryan, W.B.F. (Eds.), Deep Drilling Results in the Atlantic Ocean. Am. Geophys. Union, Maurice Ewing Ser., 3:249-274.

Abbreviations for names of organizations and publications in ODP reference lists follow
the style given in Chemical Abstracts Service Source Index (published by American Chemical Society).

Date of initial receipt: 2 October 1992

Date of acceptance: 26 April 1993

Ms 132SR-302 